\title{
Un siglo y medio de economía nicaragüense: las raíces del presente
}

Autora: Roser Solá Montserrat

Esta historia de Nicaragua, aunque con una breve referencia a la época colonial y su relación con el exterior, comienza en los años del "desarrollo hacia fuera", protagonizados por el café y la pronta intervención norteamericana, a la que

A continuación se dedica una gran atención a los cambios estructurales promovidos por la Revolución Sandinista y su preocupación por lo social y por la hombres libres. Sigue con la época del crecimiento económico acelerado, bajo la égida del somocismo: los años de la posguerra, florecientes para Nicaragua como para la mayoría de países del mundo, haciendo especial énfasis en sus protagonistas locales, algodón, hamburguesas y Mercomún. modernización del país; se analiza la los desafíos del futuro.

* Texto extraído de la Introducción del Libro.

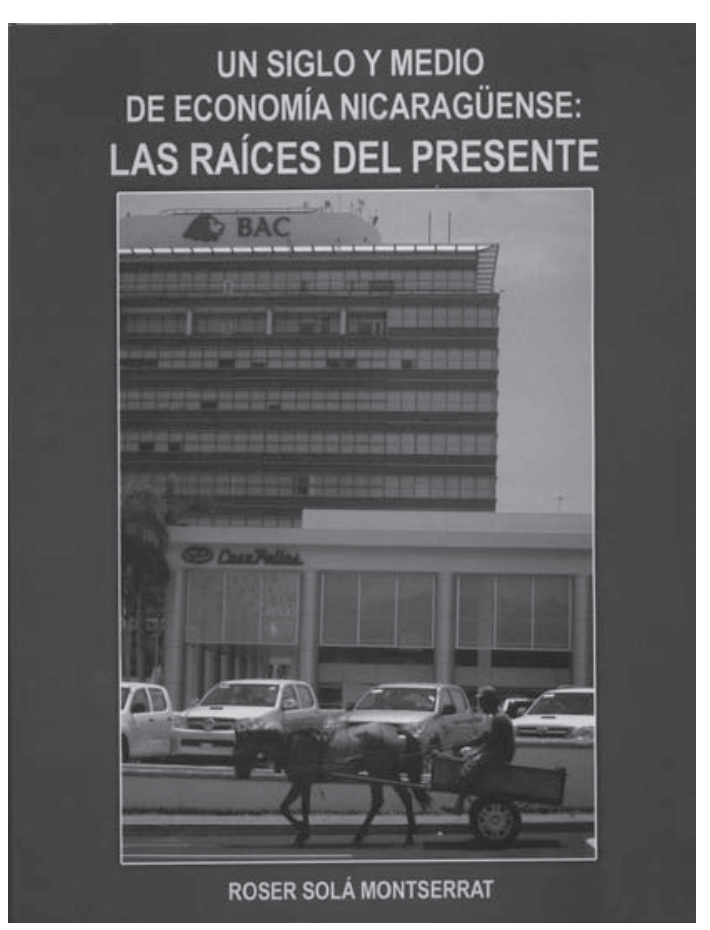
Reforma Agraria, y la política económica, social y cultural del período, con el ánimo de ofrecer un balance de lo que significaron para el país esos años de sueños y fracasos.

La pacificación emprendida por Doña Violeta y los mecanismos de ajuste estructural de los años noventa, con su exigencia de austeridad en las políticas públicas en detrimento de lo social, son tratados detenidamente por ser los conformadores de la actual estructura económica, que en la época de Bolaños se ha visto orientada hacia nuevos retos de futuro expresados en el Plan Nacional de Desarrollo.

Finalmente, en el epílogo se intentan dibujar las grandes líneas que han configurado nuestra historia, desde la época de la colonia hasta el presente, a la par que se concretizan 